\title{
神奈川県の水源環境保全・再生施策について
}

神奈川県環境農政部緑政課*

\section{The conservation and restoration policies for water source environment of Kanagawa Prefecture}

\author{
Greenery Policy Division, Environment and Agriculture Department, \\ Kanagawa Prefectural Government*
}

\begin{abstract}
要旨
神奈川県では、県民生活を支える豊かな水の恵みを将来にわたって安定的に確保するため、今後 20 年間の取組の基本指針となる「かながわ水源環境保全・再生施策大綱」および最初の 5 年間に充実・ 強化して取り組む「実行 5 か年計画」を策定し、平成19年度から、水源環境保全税を財源として順応 的管理の考え方と県民会議による県民参加に立脚した種々の水源環境保全・再生施策に取り組んでい る。

キーワード：水源環境保全・再生施策、水源環境保全税、順応的管理、県民会議
\end{abstract}

\section{1. なぜ、水源環境保全・再生が必要なのか}

本県では、相模ダム建設以来、60余年にわたり ダムの建設等による水源開発に力を注いできた。

こうした先人の努力や水源地域の方々の理解と 協力によって確保された水源は、都市化の進展に より増加した県民の生活を支え、京浜工業地帯を はじめとする本県の産業発展の礎となり、我が国 の経済発展にも大きく寄与してきた。

現在は、平成13年の宮ケ瀬ダムの完成により県 内の水需要を概ね賄うために必要な水がめが整 い、少なくとも量的な面では、当面、県民が水を 安心して利用できる状況となっている。

しかしながら、水源地域の環境を見ると、ブナ
の立ち枯れをはじめとした自然林の荒廃や戦後の 林業の経営不振等に伴う上流域の森林の荒廃に よって水源かん養機能は低下しつつあり、また、 生活排水対策の遅れなどにより、湖のアオコの発 生等、様々な問題が発生し、河川や湖の水質の低 下が危惧されている。

私たちの生活に欠かすことのできない水の恵み は、水源地域の自然環境によって育まれるもので ある。

将来にわたり、良質な水を安定的に県民が利用 できるようにするためには、水源地域の自然環境 が再生可能な今のうちから、水源環境保全・再生 の取組に着手し、長期にわたり取組を継続してい く必要がある。

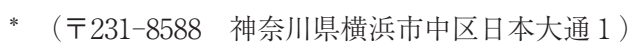




\section{2. 保有水源の現状}

県内の上水道の約 9 割は、相模川と酒匂川の 2 水系によって賄われており、その大半は、ダムに より開発された水となっている。

県の中央を南北に流れる相模川は、本川に相模 ダム（相模湖）と城山ダム (津久井湖)、支流の中 津川に宮ケ瀬ダム（宮ヶ瀬湖）の3つの水源があ り、その集水域の約 8 割は山梨県内に広がってい る。これらのダムにより開発された水は、下流の 相模大堰、寒川取水堰などで取水されている。ま た、県の西部を南北に流れる酒匂川は、支流の河 内川に三保ダム（丹沢湖）があり、その開発水は 下流の飯泉取水堰で取水されている。

また、地下水等は、県全体の水源の7.4\%だが、 県西部地域の市町や秦野市、座間市などの主要な 水道水源となっている。

このように、本県の水道水源は、主としてダム により賄われているが、県民すべての水源を保全 するためには、県外上流域から下流の取水堰に至 る集水域の全体と地下水等の地域固有の水源周辺 の環境を良好な状態に保つ必要がある。

\section{3. 水源環境保全・再生の施策実現に向けた検討}

\section{1 県による水源環境保全・再生施策の取組 に向けた検討}

水源環境の保全・再生については、県ではこれ までも平成 9 年に水源の森林づくり計画を策定

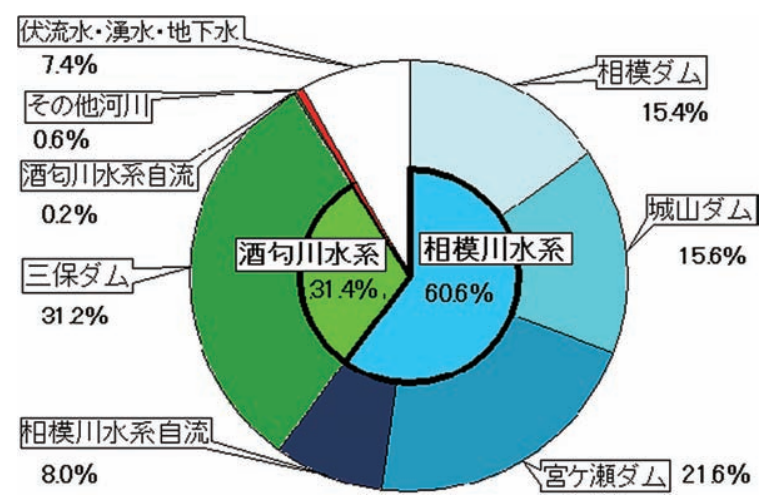

図 2 神奈川県内の上水道の水源別構成比（平成17 年度)

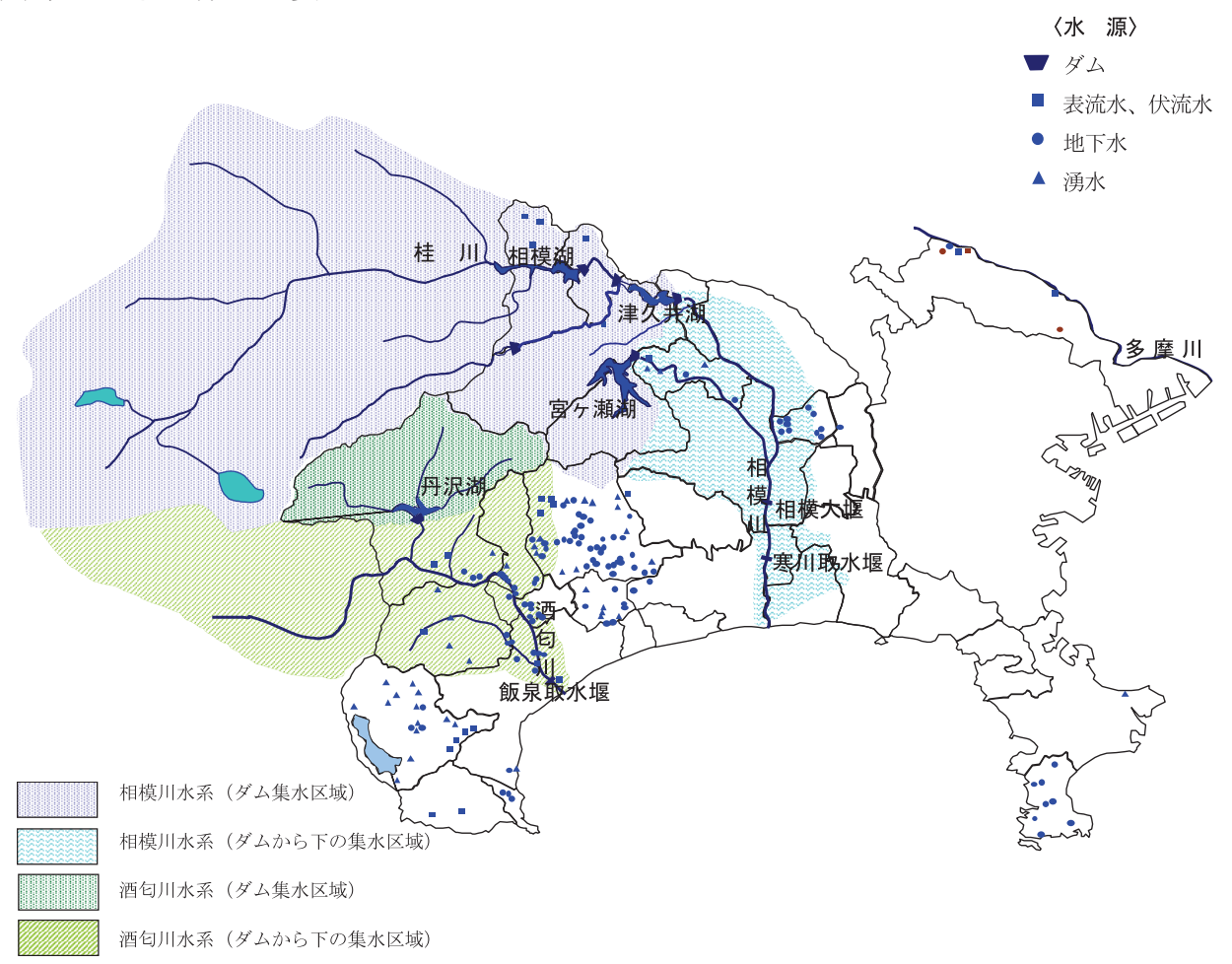

図 1 神奈川県の上水道水源の概況 
し、森林の保全に取り組んできた。

また、市町村と連携して森林保全や水質保全な どの様々な事業に取り組んできており、水道事業 者も、利用者からの水道料金の中で水道施設やダ 么等の水源施設の整備及び維持管理などのほか、 水源林の保全や生活排水対策に対する支援などに 努めてきた。

しかし、良質で豊かな水の恵みを育む水源環境 を保全・再生していくためには、さらに充実・強 化した取組を、体系的かつ長期的・継続的に推進 していく必要があることから、県では、水源環境 保全・再生に向けた体系的・長期的な取組計画の 策定と、これを実現化する具体的な事業の取組計 画の策定に向けた検討を行った。

\section{2 水源環境保全・再生に向けた財源措置の 必要性}

県では、前述のような背景から、水源環境保 全・再生に向けた計画を策定していくこととした が、一方で、さらに充実・強化した取組を体系 的・長期的に、かつ、安定的・継続的に推進して いくためには、これらの施策の推進の裏付とな る、安定的な財源の措置も必要である。

そこで、今後取り組む水源環境保全・再生の取 組を推進するための財源のあり方についても検討 を行った。

\section{3 神奈川県地方税制等研究会からの提言}

平成10年に県が設置した、有識者で構成する神 奈川県地方税制等研究会から、平成 12 年 5 月に、 水源環境の保全や大気污染対策など、県民生活に 関わる環境課題に対する取組を促進するため、県 民の意志を基盤として構築する「生活環境税制」 の考え方が提言された。

また、平成15年10月には、水源環境の総合的な 保全・再生の視点に立って、緊急的又は中長期的 に実施する必要がある具体的な保全施策と、その ために必要な税制措置についての提言が行われ た。

\section{4 県民との論議、市町村等との検討等}

こうした提言を受け、県では、水源環境保全・ 再生のための施策のあり方や具体的な方策等の諸
課題、さらには税制措置等について、平成13年度 から「出前懇談会」や「シンポジウム」、「県民集 会」、そのほか地域県民懇話会など既存の各種会 議等を通じて県民と様々な形で論議し、幅広い意 見を集めて検討を深めた。

また、水源環境保全・再生については、県だけ でなく、市町村や水道事業者も様々な事業を実施 してきていたことから、今後の水源環境保全・再 生施策のあり方等について、市町村や水道事業者 との間においても、様々な意見交換を行った。

\section{5 水源環境保全・再生施策の計画策定}

県では、水源環境保全・再生施策の取組と財源 のあり方について、前述の様々な検討結果を取り まとめ、まず、県として、平成16年 9 月に水源環 境保全・再生の「基本計画素案」を策定し、これ に基づき、県民参加用冊子を配布するなど多様な 媒体を活用した情報提供を積極的に行うととも に、県民参加・市町村参加（パブリック・コメン

卜）を実施して多くの意見・提案を集めた。

これらの意見を踏まえ、同年12月に「基本計画 案」を、平成 17 年 2 月に「基本計画最終案」をと りまとめ、平成17年 6 月には、20年間の取組全体 を示す「かながわ水源環境保全・再生施策大綱 (案)」と、施策大綱を踏まえ最初の 5 年間に取り 組む「かながわ水源環境保全・再生実行 5 か年計 画 (案)」をとりまとめ、県議会に報告するととも に、この財源を確保するため、個人県民税に超過 課税（いわゆる【水源環境保全税】）の措置を講じ る県税条例の改正案など関係条例を提案した。

その後、県議会でさらに踏み込んだ議論を行っ た結果、平成 17 年 9 月県議会において、関係条例 が成立し、平成19年度から施策・事業を実施して いくことが承認された。

\section{4.「かながわ水源環境保全・再生施策大綱」、 「実行 5 か年計画」の概要}

神奈川県では、この「水源環境保全・再生施策 大綱」及び「同実行 5 か年計画」に基づき、水源 環境保全税を財源として、平成19年 4 月からこの 施策・事業をスタートし、現在、積極的な取組を 推進しているところである。 


\section{1 かながわ水源環境保全・再生施策大綱}

「かながわ水源環境保全・再生施策大綱」は、20 年間を視野に入れた水源環境保全・再生施策を総 合的・体系的に推進するための取組の基本的考え 方や分野ごとの施策展開の方向性などを示してい る。

\section{2 かながわ水源環境保全・再生実行 5 か年 計画}

施策大綱に基づき、水源環境保全・再生の取組 を効果的かつ着実に推進するため、20年間の第 1 期の 5 年間に充実・強化して取り組む特別の対策 について明らかにしている。

\section{【実行 5 か年計画の12事業】}

\section{(1)水源の森林づくり事業の推進}

水源の森林エリア内の私有林の公的管理 - 支援 を一層推進し、水源かん養機能等の公益的機能の 高い水源林として整備する。（ 5 年間の新規必要 額：8,393百万円）

\section{(2)丹沢大山の保全 ・再生対策}

土壤流出防止対策を行うとともに、ブナ林等の 保全・再生のための研究や樹幹保護などの県民協 働の事業に取り組む。（ 5 年間の新規必要額：796 百万円）

\section{(3)渓畔林整備事業}

水源上流の渓流両岸において、土砂流出防止や 水質浄化、生物多様性の保全など森林の有する公 益的機能を高度に発揮するための森林整備を実施 する。( 5 年間の新規必要額：200百万円）

\section{(4)間伐材の搬出促進}

森林資源の有効利用による森林整備を推進する ため、間伐材の集材・搬出に対し支援する。（5 年間の新規必要額：409百万円)

\section{(5)地域水源林整備の支援}

地域に拈ける水源保全を図るため、市町村が主 体的に取り組む水源林の確保・整備を推進するほ か、高齢級の私有林人工林の間伐を促進する。 （ 5 年間の新規必要額：949百万円）

表 1 かながわ水源環境保全・再生施策大綱

\begin{tabular}{|c|c|}
\hline 計画期間 & 平成 $19 \sim 38$ 年度 \\
\hline 的 & 良質な水の安定的確保 \\
\hline 理 念 & $\begin{array}{l}\text { 河川の県外上流域から下流まで、河川や地下水脈の全流域、さらには水の利用関係で結ばれた都市地 } \\
\text { 域を含めた地域全体（水の共同利用圈域）で自然が持つ水循環機能の保全・再生を図る。 }\end{array}$ \\
\hline $\begin{array}{c}\text { 施策展開 } \\
\text { の視点 }\end{array}$ & $\begin{array}{l}\text { ○総合的な施策推進 } \\
\text { ○県民の意志を基盤とした施策展開 } \\
\text { ○順応的管理の考え方に基づく施策推進 }\end{array}$ \\
\hline 対象地域 & $\begin{array}{l}\text { 主として、県外上流域を含めたダム上流域を中心に、河川水及び地下水の取水地点の集水域全体 } \\
\text { (水源保全地域) }\end{array}$ \\
\hline
\end{tabular}

表 2 かながわ水源環境保全・再生実行 5 か年計画

\begin{tabular}{|c|c|}
\hline 計画期間 & 平成 $19 \sim 23$ 年度 \\
\hline 対象事業 & $\begin{array}{l}\text { ○水源環境の保全・再生への直接的な効果が見込まれるもので、県内の水源保全地域を中心に実施 } \\
\text { する取組 } \\
\text { ○水源環境保全・再生を進めるために必要な新たな仕組みを構築する取組 }\end{array}$ \\
\hline $\begin{array}{l}\text { 事業数と } \\
\text { 新規必要額 }\end{array}$ & $\begin{array}{l}12 \text { 事業 } \\
5 \text { 年間の総額 : 約 } 190 \text { 億円、年度平均 : 約 } 38 \text { 億円 }\end{array}$ \\
\hline
\end{tabular}


6河川・水路における自然浄化対策の推進

市町村管理の河川・水路等における良好な水源 環境を形成するため、市町村が主体的に取り組む 水辺環境の整備や直接浄化などを推進する。（5 年間の新規必要額：1,122百万円）

\section{7)地下水保全対策の推進}

地下水を主要な水道水源として利用している地 域を中心に、各市町村が主体的に取り組む地下水 かん養対策や水質保全対策を推進する。（5 年間 の新規必要額 : 1, 165百万円)

8)県内ダム集水域における公共下水道の整備促進

県内夕゙么集水域における生活排水処理率の向上 をめざして、市町村が実施する公共下水道の整備 を支援する。（5 年間の新規必要額：4, 270 百万円） (9)県内ダム集水域における合併処理浄化槽の整備 促進

県内ダム集水域における生活排水処理率の向上
をめざして、市町村が実施する合併処理浄化槽 （高度処理型）の整備を支援する。（ 5 年間の新規 必要額：646百万円)

\section{(10)相模川水系流域環境共同調査の実施}

相模川水系県外上流域の森林の現況や桂川・相 模川全流域の水質污濁負荷の状況等について環境 調査を実施する。（ 5 年間の新規必要額：98百万 円）

\section{1水環境モニタリング調査の実施}

森林、河川、地下水などのモニタリング調査を 行い、事業の実施効果を測定するとともに、水源 環境情報を白書等で提供する。（ 5 年間の新規必 要額：848百万円)

(12)県民参加による水源環境保全·再生のための新 たな仕組みづくり

水源環境保全・再生の取組を支える県民の意志 を施策に反映し、施策の計画や事業の実施等に県

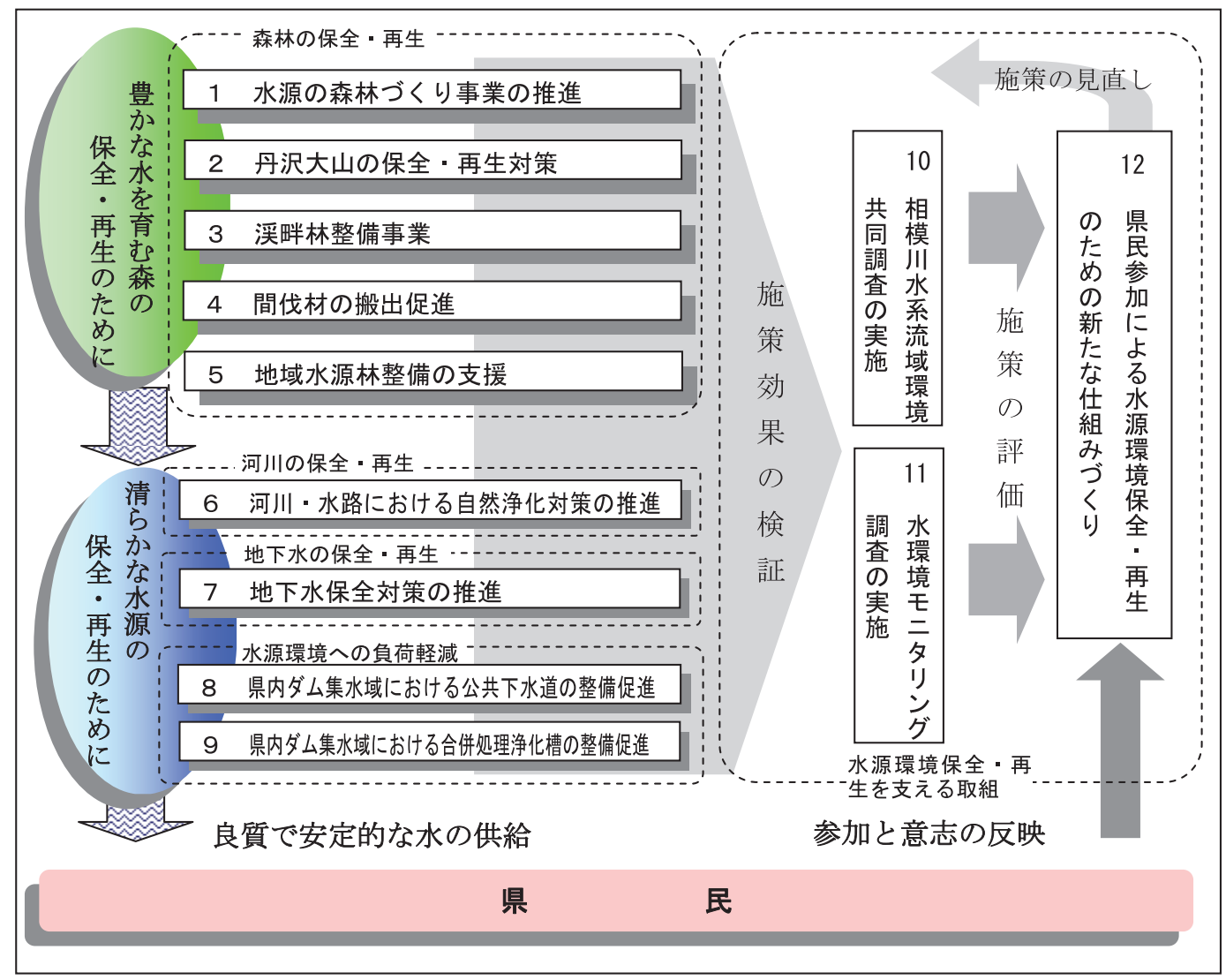

図 3 実行 5 か年計画の 12 事業 
民が直接参加する仕組みを作る。（ 5 年間の新規 必要額：192百万円)

\section{5. 順応的管理の考え方に基づく施策の推進と県 民の意見を反映させる仕組み}

\section{1 順応的管理の考え方に基づく施策の推進}

水源環境の保全・再生の取組は、自然を対象と したものであり、施策の実施によりどのような効 果が現れるかについては、当該施策だけではな く、他の施策や自然条件によって大きく左右され る。また、現在の科学的知見では将来の自然環境 に及ぼす影響を正確に把握することには限界があ る。

そのため、事業の実施と並行して、事業実施に 伴う自然環境の状況を把握しながら、施策の評価 と見直しを行い、柔軟な施策の推進を図る必要が ある。

そこで、水源環境保全・再生施策の推進に当 たっては、このような順応的管理の考え方に立 ち、着実かつ効果的な計画の推進を図ることとし た。

\section{2 県民の意見を施策に反映させる仕組み}

水源環境の保全・再生の取組は、「県民が自分 たちの住む生活空間にどのような快適さをもとめ るのか」という意志を基盤として構築する「生活 環境税制」の理念を踏まえて具体化を検討したも のである。

このため、森林の保全・再生などをはじめ、水 源環境の保全・再生には、長期にわたる継続的な 取組が必要であるが、県民の意志を基盤とし、県 民に新たな負担を求めて施策を充実・強化するの であれば、施策に県民の意志を反映し、県民に施 策効果を明示すること、さらには施策の見直しや 立案、実施に県民自身も参加できる仕組みも必要 である。

そこで、県民参加のもとで、水源環境保全・再 生施策を推進するための新たな仕組みとして、有 識者・関係団体 ·公募委員を構成員とする「水源 環境保全・再生かながわ県民会議」を平成19年 4 月に創設した。

\section{3 順応的管理の考え方と県民会議の議論に 基づく水源環境保全・再生施策の推進}

現在、前述の順応的管理の考え方と県民参加の 取組を併せて推進しているところであり、「水源 環境保全・再生かながわ県民会議」と行政が協働 し、県民参加のもとで、モニタリングや県民に対 する普及啓発活動を実施している。

また、施策の立案・事業の実施・評価・見直し の各段階において、県民の意見を施策に反映して いく取組みを進め、順応的管理の考え方に基づ き、望ましい水源環境作りに向けて、水源環境保 全・再生施策を推進している。

\section{6. 個人県民税の超過課税（水源環境保全税）の 概要}

水源環境の保全・再生に継続的、安定的に取り 組むには、景気の動向等に左右されやすく、不安 定な一般財源とは別に、水源環境保全・再生のた めの安定した財源を新たに確保することが必要な ことから、この実行 5 か年計画に位置付けた $12 の$ 特別対策を推進するため必要となる年間約38億円 の財源を、水を利用する県民に広く負担してもら うため、個人県民税の均等割と所得割に対する超 過課税を実施している。

また、この税が水源環境保全・再生施策に活用 されることをより明確にするため、県の一般会計 とは別に、新たに特別会計（神奈川県水源環境保 全・再生事業会計）と、その特別会計の中に基金 （神奈川県水源環境保全・再生基金）を同時に創設 した。

\section{○実施時期}

平成19年 4 月 1 日から 5 年間（平成19年度分か ら平成23年度分まで）

○税率

\section{表 3 税率}

\begin{tabular}{|c|c|c|c|}
\hline \multirow{2}{*}{ 区分 } & \multicolumn{3}{|c|}{ 平成19年度分からの制度内容 } \\
\cline { 2 - 4 } & $\begin{array}{c}\text { 標準税率 } \\
(\text { ア }\end{array}$ & $\begin{array}{c}\text { 新たなご負担 } \\
(イ)\end{array}$ & $\begin{array}{c}\text { 合計 } \\
(\text { ア }+ \text { イ })\end{array}$ \\
\hline 均等割 & 1,000 円 & 300 円 & 1,300 円 \\
\hline 所得割 & 一律 $4 \%$ & $0.025 \%$ & $4.025 \%$ \\
\hline
\end{tabular}


税収規模

年額 約38億円（ 5 か年で約190億円）

○納税者一人当たりの平均負担額

年額 約950円（月額 79円）

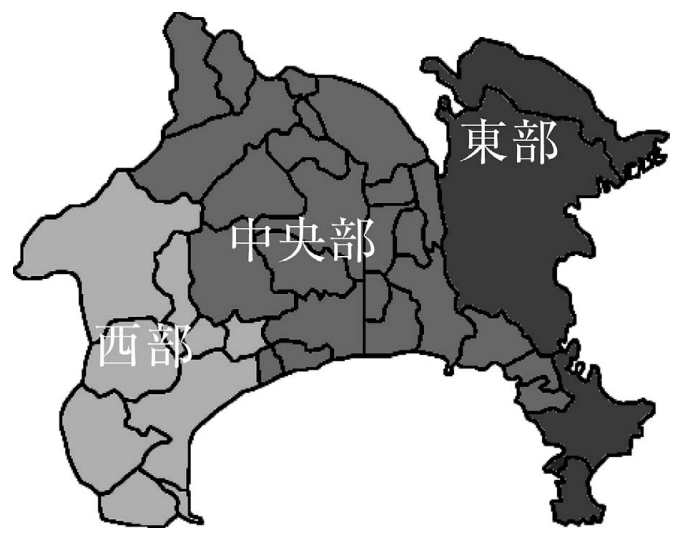

図 4 地域区分図

\section{7. 地下水の保全・再生}

前述のとおり、本県では、森林、河川、地下水 及び生活排水対策など、さまざまな水源環境保 全・再生施策に取り組んでいるところだが、ここ では、地下水の現状、将来像、施策展開の方向性 及び現在の取組事例について述べる。

\section{1 現状}

\section{1.1 地下水利用と地下水位}

本県では水道水源としての地下水の割合は、伏 流水、湧水を含めて $7.4 \%$ であるが、西部地域で は36.7\%を占めている。また、中央部地域でも、 秦野市は自己水源の約 9 割、座間市は自己水源の 全量が地下水となっており、本県の重要な水源と なっている。

地下水の水量面について見ると、地下水の汲上 げによる著しい地盤沈下や塩水化といった障害は 現在では見られないものの、地下水位は従前に比

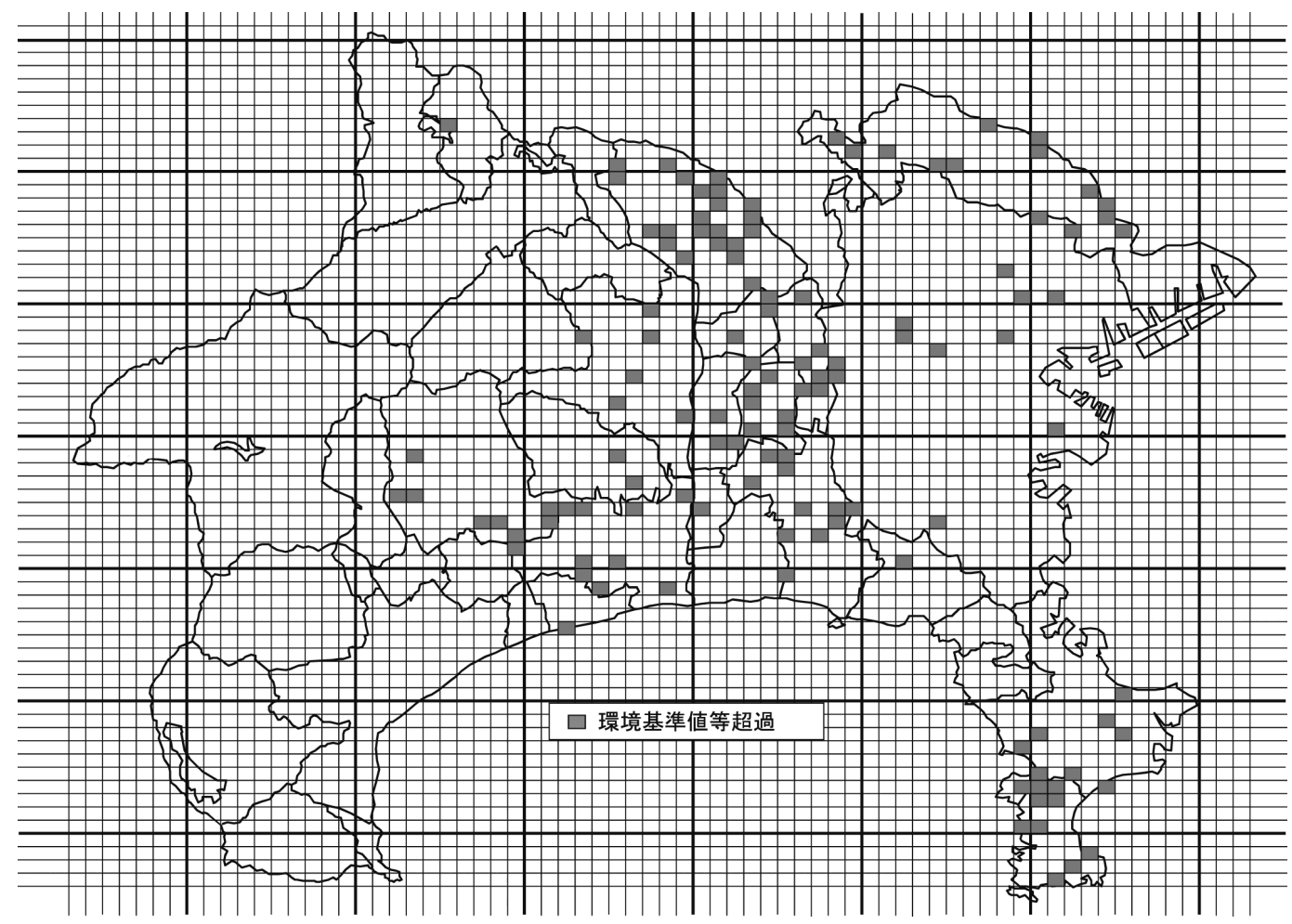

図 5 地下水污染状況（平成14～17年度） 
ベると低下している。

\section{1 .2 地下水の水質}

地下水の水質を見ると、県内各地で硝酸性窒素 及び亜硝酸性窒素、有機塩素系化合物等が環境基 準を超過している。水道水源になっている地下水 についても、污染が発見された例もあり、現在、 取水を停止している水源もある。

\section{2 将来像}

\subsection{1 持続可能な地下水利用}

地下水、伏流水、湧水を水道水源として利用し ている地域において、地下水の適正な利用と保全 により、将来にわたり地下水利用や環境面に影響 のない水位レベルを維持し、持続可能な水利用を 目指守。

\section{2 .2 地下水污染のない水道水源地域}

地下水を水道水源として利用している地域内に おいて、地下水の水質が環境基準以下の数值とな ることを目指す。

\section{3 施策展開の方向性}

\subsection{1 地域主体の地下水保全対策の推進}

本県では、従来から、県全域を対象として、地 盤沈下対策、湧水の保全、地下水污染対策などの 地下水保全の取組を推進してきた。

また、地下水は一度污染されると再び水源とし て使えるようにすることは容易ではないことか ら、県では水質污濁防止法や県生活環境の保全等 に関する条例に基づき、工場等に対して有害物質 による地下水污染の未然防止や、污染した地下水 の浄化等の指導を行っている。

しかし、水源としての地下水を見た場合、県西 部の市町村や秦野市、座間市などでは主要な水道 水源として利用されているが、その他の地域で は、水道水等の生活用水としての利用は少なく、 地下水の利用状況や地下水をめぐる環境には大き な地域差がある。こうした地下水をめぐる地域差 を考えると、地域特性に応じた地下水保全対策を 推進することが必要である。

一部の市町村では独自に条例や計画を定めて地 下水保全に取り組んでいるところもあるが、今 後、こうした市町村など地域を主体とする取組を より一層推進する必要がある。
そこで、地下水を主要な水道水源としている地 域において、それぞれの地域特性に応じた地下水 保全対策を推進するため、市町村が主体的に行う 地下水のかん養や水質保全等の取組を支援する。

\section{3 .2 地下水の保全・利用に係る広域的な管 理}

地下水は市町村域を越えて流動しているため、 ある市町村における新規の地下水利用や地下水污 染事故などが、地下水を水道水源とする別の市町 村の大きな不安要因となっている。

地下水の保全を的確に推進するためには、各地 域における地下水の流動機構や水収支、地下水質 の污濁と浄化のメカニズム（仕組み）などの実態 を総合的に把握することが必要であるが、デー夕 及びその収集体制は十分とは言えない。

そのため、市町村域を越えた地下水の流動を的 確に把握するための広域的な体制づくりを図る必 要がある。

そこで、地下水を水道水源として利用している 地域に打いて、地下水の適正な利用と保全を図る ため、関係する周辺地域を含めて地下水の水位や 水質、利用状況などの継続的なモニタリング調査 や観測網の整備を推進し、的確な地下水の管理を 図っていくこととする。

また、地下水の流動が複数の市町村域にまた がっている場合は、その利用と保全について整合 の取れた効果的な地下水保全の取組を実施できる よう、関係者間の協議や情報交換、調整の場づく りを行い、関係市町村の連携による広域的な地下 水の管理を推進する。

\section{4 現在の取組事例}

現在、水源環境保全税を財源とした地下水保全 対策は、市町村が主体となって実施している。こ こではその主な取組事例を紹介する。

\section{4.1 地下水かん養対策}

秦野市では、水田の地権者などの協力を得て、 稲作後の水田や休耕田を利用して農業用水を引き 込み、地下に浸透させる取組を実施している。

また、秦野市、座間市及び開成町では、雨水浸 透ますの設置者に対し、設置費用を補助する取組 を実施している。 


\section{4 .2 地下水污染対策}

秦野市では、有機塩素系化学物質による地下水 污染への対策として、市内 3 箇所に浄化装置を設 置し、汲み上げた地下水を浄化して地下に戻す取 組を実施している。

\section{4 .3 地下水モニタリング}

足柄上地区の 1 市 5 町（南足柄市、中井町、大
井町、松田町、山北町及び開成町）は、「足柄上 地区地下水保全連絡会議」を組織し、連携して地 下水保全対策に取り組んでいる。現在、1市 5 町 で策定した計画に基づき、広域的な地下水モニ夕 リング体制の構築を進めている。

(受付：2009年11月27日、受理：2010年 1 月13日) 